\title{
Rim-ba: Karya Tari Hasil Refleksi Kehidupan Suku Anak Dalam
}

\author{
Sarjiwo dan Widyanarto ${ }^{1}$ \\ Jurusan Seni Tari, Fakultas Seni Pertunjukan ISI Yogyakarta.
}

\begin{abstract}
ABSTRAK
Karya tari "Rim-ba" merupakan hasil dari refleksi penata tari terhadap kehidupan Suku Anak Dalam (Orang Rimba) di Bukit Duabelas Propinsi Jambi. Hutan yang menjadi habitat dan tempat bernaung Suku Anak Dalam semakin sempit areanya. Hal tersebut disebabkan oleh adanya penebangan liar (illegal logging) maupun perluasan lahan perkebunan sawit. Tema yang diangkat dalam garapan karya tari ini adalah perjuangan hidup orang rimba. Bentuk penyajiannya simbolis representasional yang terbagi dalam empat adegan, yaitu adegan satu (introduksi) tentang keterbelakangan, adegan dua tentang ritus orang rimba, adegan tiga tentang aktivitas mata pencaharian orang rimba, dan adegan empat tentang perusakan rimba. Karya tari ini didukung oleh empat orang penari. Gerak tari berorientasi pada perilaku kehidupan sehari-hari orang rimba. Musik pengiring merupakan musik hasil editing secara digital dengan software nuendo dengan memasukkan unsur suara vocal. Tata rupa pentas berdasar pada atmosfir suasana hutan, meliputi property instalasi kayu, akar sulur gantungan dan dedaunan. Busana yang dikenakan menyerupai busana asli Suku Anak Dalam yang sudah dimodifikasi. Sedangkan tata cahaya yang digunakan berorientasi pada nuansa cahaya alam.
\end{abstract}

Kata kunci: rimba, suku anak dalam, bukit duabelas

\section{ABSTRACT}

"Rim-ba": A Dance reflecting the Life of Anak Dalam Tribe. Rimba dance is the result of the choreographer's reflection on the life of Anak Dalam tribe (forest people / Orang Rimba) in Bukit Duabelas, Jambi province. The forest which is the habitat of the tribe is shrinking. This is due to the illegal logging and palm oil agriculture expansion. The theme of the dance is about the struggle of forest people in their life. The symbolic, choreographic representation is divided into four acts; the first act introduces the underdeveloped condition of the people; the second act shows the rituals practiced by the forest people; the third act shows how the forest people earn their living; and the final act visualizes the forest destruction. The dance is performed by four dancers. The dance movement orientates on the daily behaviors of the forest people. The accompanying music is composed and edited digitally by applying nuendo software and inserting vocal element in the software. The stage decoration shows a forest setting which includes wooden property, hanging roots and leaves. The dancers' costumes resemble the original clothes of Anak Dalam tribe along with some modifications, whereas the lighting arrangement is based on natural lighting nuance.

Key words: anak dalam dance, bukit duabelas

\section{Pendahuluan}

Karya tari Rim-ba merupakan sebuah karya reflektif dari hasil observasi penata tari terhadap berbagai macam ritus dan kehidupan Suku Anak Dalam (Orang Rimba) di Propinsi Jambi. Departemen Sosial Republik Indonesia menamakan Suku Anak Dalam (Orang Rimba) sebagai kelompok suku bangsa minoritas yang hidup terisolasi sebagai masyarakat terasing. Suku Anak Dalam berdiam antara lain di daerah sungai Sorenggom, sungai Terap, sungai Kejasung besar/kecil, sungai Makekal dan sungai Sukalado di kawasan Taman Nasional Bukit Dua
Belas (TNBD) Propinsi Jambi. Taman Nasional Bukit Duabelas (TNBD) ditetapkan berdasarkan surat keputusan Menteri Kehutanan Nomor 258/Kpts-11/2000, tanggal 23 Agustus 2000. Kawasan TNBD mencakup areal seluas 58.3000 $\mathrm{Ha}$ (data sementara Bip.Hut, 2004). Presiden RI pada tanggal 26 Januari 2001, yang bertempat di Jambi mendeklarasikan terbentuknya Taman Nasional Bukit Duabelas (TNBD). Kawasan TNBD pada hakekatnya merupakan perluasan dari kawasan lindung atau Cagar Biosfer Bukit Duabelas (CBBD), yang selama ini merupakan kawasan yang diperuntukkan bagi Suku Anak

1 Alamat Korespondensi: Prodi Tari ISI Yogyakarta. Jalan Parangtritis KM 6,5 Sewon, Yogyakarta 55001. Telepon 0274 8337889; 08157888 7707. E-mail: sarjiwo_tari@yahoo.co.id 
Dalam (Orang Rimba). Dinamakan Bukit Duabelas karena menurut Suku Anak Dalam, bukit tersebut memiliki duabelas undakan atau jenjang untuk sampai di puncaknya. Pada tempat inilah menurut mereka banyak terdapat roh nenek moyang mereka, dewa-dewa dan hantu-hantu yang bisa memberikan kekuatan.

Asal-usul komunitas Suku Anak Dalam (Orang Rimba) ada beberapa versi cerita, salah satunya versi cerita dari Tumenggung Tarib. Tumenggung Tarib menceritakan bahwa pada suatu ketika para pasukan dari Raja Pagaruyung tersesat di tengah hutan dalam perjalanan menuju Jambi untuk membantu Raja Jambi yang bernama Ratu Selaras Pinang Masak. Pasukan tersebut akhirnya memutuskan untuk tinggal dan mengisolasikan diri dalam hutan. Mereka bersumpah bahwa: "Ke mudik dikutuk rajo Minangkabau, ke ilir dikutuk rajo Jambi, ke atas tidak berpucuk, di tengahtengah dimakan kumbang, di timpo kayu punggur". Maksudnya adalah mereka tidak berani kembali ke Minangkabau karena pasti dihukum oleh Raja, jika terus ke Jambi bekal sudah habis. Mereka sepakat untuk tinggal di tempat mereka tersesat, walaupun perbekalan habis akan tetapi masih bebas dan tidak takut dikutuk raja.

Suku Anak Dalam (Orang Rimba) merupakan masyarakat hutan yang benar-benar hidup dan tinggal di dalam keteduhan dan kelebatan hutan. Orang Rimba berkeyakinan bahwa mengubah alam adalah pembangkangan terhadap kehendak Tuhan dan merupakan pelanggaran adat (Aritonang, 2005: 5). Komunitas Orang Rimba mempercayai adanya dewa-dewa yang melindungi kehidupan mereka seperti dewa gajah, dewa harimau, dewa batu, dewa langit, dewa kayu dan lain-lain. Propinsi Jambi memiliki banyak suku, yaitu Suku Bajau, Suku Orang Batin, Suku Kerinci, Suku Orang Penghulu, Suku Pindah, Suku Melayu Jambi, Orang Asing, dan Orang Rimba. Menurut para antropolog, Suku Anak Dalam (Orang Rimba) adalah suku yang masuk ke dalam golongan Proto Melayu atau Melayu tua, salah satu masyarakat asli Jambi. Mereka merupakan salah satu komunitas adat terpencil di Propinsi Jambi yang mempunyai adat istiadat yang spesifik, yaitu mendudukkan adat istiadat yang berbeda dengan masyarakat pada umumnya. Tatanan adat istiadat Suku Anak Dalam terdapat selako (semboyan adat), mantera, dan melangun.
Melangun adalah meninggalkan tempat tinggal untuk beberapa tahun dan berpindah ke kawasan lain jika ada salah satu dari mereka meninggal dunia. Melangun juga dapat diartikan sebagai kegiatan meninggalkan lokasi tempat asal menuju ke suatu tempat yang baru, dapat juga diartikan sebagai mengembara mencari tempat kehidupan yang layak untuk mencukupi kebutuhan dan menjamin kelangsungan hidup. Aktivitas melangun mereka lakukan apabila terjadi kematian, paceklik, dan wabah penyakit. Selain itu budaya Suku Anak Dalam (Orang Rimba) yang masih terjaga sampai sekarang adalah adat perkawinan (pertunangan, upacara perkawinan, pernikahan), adat kelahiran (pantangan dan larangan, upacara sirih badan, melahirkan, dan pengaturan kelahiran), serta adat kematian (upacara bersale dan pemakaman jenazah). Menurut kepercayaan Suku Anak Dalam (Orang Rimba) upacara atau ritual perkawinan, kelahiran, dan kematian tidak boleh disaksikan oleh orang luar selain Orang Rimba, karena dapat menyebabkan para dewa tidak mau datang sehingga upacara tidak dapat dilangsungkan.

Gaya hidup Suku Anak Dalam secara tradisional, yaitu hunters (berburu) dan gatherers (meramu atau mengumpulkan makanan) yang hidup secara berpindah- pindah. Oleh karena itu mereka sangat tergantung dengan hasil hutan (alam) dan binatang buruan. Pada saat ini sudah banyak yang mengkonsumsi beras sebagai makanan pokok sehari-hari. Makanan pokok mereka pada waktu dulu adalah segala jenis umbiumbian yang tumbuh di hutan, seperti keladi, ubi kayu, ubi jalar, umbi silung dan binatang buruan seperti babi hutan, rusa, kancil, lebah madu serta menangkap ikan. Suku Anak Dalam (Orang Rimba) hidup secara berkelompok dalam satu wilayah yang dikepalai oleh seorang Tumenggung. Tempat tinggal mereka di dalam hutan belantara. Setiap pondok (sudung) satu keluarga terpisah agak jauh dengan sesudung keluarga yang lainnya. Bagi anak-anak mereka yang sudah besar dibuatkan sudung sendiri yang tidak jauh dengan sudung orang tuanya. Sesudung dalam bahasa mereka berarti rumah. Rumah didirikan di atas batangbatang kayu bulat kecil panjang yang disusun berjajar sehingga dapat digunakan sebagai alas.

Suku Anak Dalam (Orang Rimba) pada umumnya tidak menggunakan pakaian, namun mereka menggunakan cawat kain untuk menutupi 
kemaluannya. Pada masa lampau mereka menggunakan cawat dari kulit kayu terap atau serdang, akan tetapi pemakaian cawat dari kulit kayu sering menimbulkan rasa sakit akibat kutu kayu yang masuk ke dalam kulit. Oleh karena itu mereka meninggalkannya dan beralih dengan kain yang mereka beli di pasar melalui masyarakat umum. Kaum wanita sangat sulit dijumpai. Hal tersebut dikarenakan ada larangan kaum wanita untuk keluar. Bahkan kalau mereka melihat orang luar (bukan anggota suku) selalu lari menghindar.

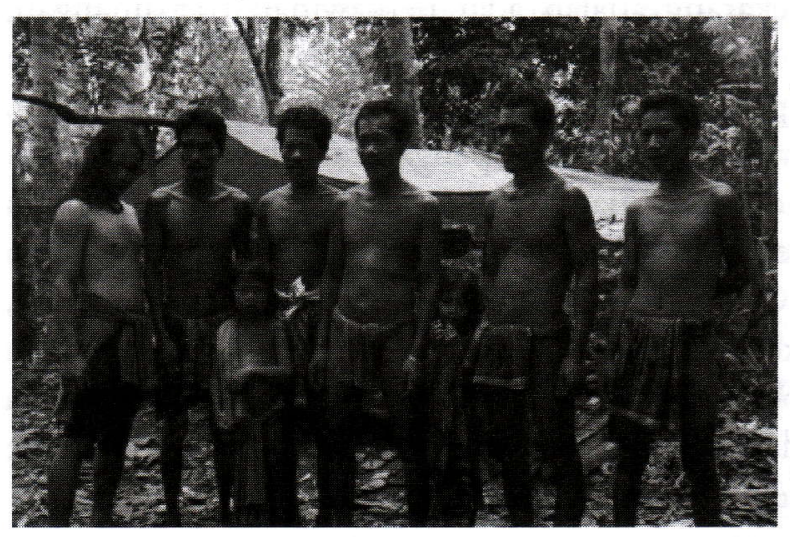

Penata Tari (paling kiri) bersama Suku Anak Dalam (Orang Rimba) di Taman Nasional Bukit Duabelas Propinsi Jambi

(Foto: Dokumen Widyanarto, 2009)

Walaupun pada umumnya Suku Anak Dalam hidup secara berkelompok, akan tetapi keberadaan kelompok ini tidak dibatasi oleh wilayah tempat tinggal tertentu. Susunan organisasi sosial pada masyarakat Suku Anak Dalam terdiri dari Tumenggung merupakan kepala adat, wakil Tumenggung sebagai pengganti Tumenggung jika berhalangan, Depati merupakan pengawas terhadap kepemimpinan Tumenggung, Mentri bertindak untuk menyidang orang secara adat, Debalang Batin adalah pengawas Tumenggung, Tengganas atau Tengganai sebagai pemegang keputusan tertinggi sidang adat dan dapat membatalkan keputusan.

Intensitas hubungan sosial Suku Anak Dalam (Orang Rimba) dengan masyarakat luar masih dalam skala terbatas. Pemahaman bahwa: "Orang Rimba tinggal di rimba, orang luar tinggal di luar hutan dan tidak boleh bercampur" masih dipegang kuat. Pada dasarnya kehidupan orang rimba sangat keras, mereka hanya mematuhi hukum yang mereka ketahui yaitu adat istiadat.
Oleh karena Suku Anak Dalam masih sangat menjaga adat dan tradisinya, maka untuk membaur ke dalam masyarakat luas, memerlukan waktu yang lama. Akan tetapi sudah ada indikasi bahwa kalangan anak muda mulai mengalami perubahan. Kalangan muda pada saat ini lebih terbuka dalam membina hubungan sosial dengan masyarakat luar. Realitas yang terjadi bahwa keberadaan antara masyarakat luar dengan Suku Anak Dalam (Orang Rimba) ada jalur pemisah. Menurut pandangan masyarakat Jambi, bahwa sebutan yang diberikan bagi Suku Anak Dalam adalah Orang Kubu. Pengertian Orang Kubu dalam bahasa Melayu Jambi berarti tempat persembunyian atau bodoh. Suku Anak Dalam sendiri tidak suka dan sangat marah bila disebut Orang Kubu, karena sangat tidak enak didengar dan ada kesan merendahkan. Mereka lebih suka disebut sebagai Anak Dalam, Orang Rimba atau Orang Kelam, sedangkan orang desa di sekitarnya disebut orang terang.

Adanya interaksi antara masyarakat desa dengan komunitas Suku Anak Dalam (Orang Rimba) di Taman Nasional Bukit Dua Belas dalam aspek pemanfaatan sumber daya alam, mendorong pihak pengelola yaitu Badan Konservasi Sumberdaya Alam Propinsi Jambi dan salah satu lembaga swadaya masyarakat yang berupaya menjaga kelestarian TNBD yaitu Komunitas Konservasi Indonesia Warsi (KKI Warsi), mengadakan pendidikan konservasi untuk mewujudkan keseimbangan antara pemanfaatan dan pelestarian sumberdaya alam serta sumberdaya manusia secara bertanggung jawab. Menurut Robert Aritonang koordinator program orang rimba KKI Warsi, bahwa cara pandang terhadap suku-suku asli selama ini disadari kurang tepat. Aspek pertama dari kekeliruan ini telah menimbulkan dampak negatif terhadap kehidupan suku-suku asli yang tidak diperhatikan sebelumnya. Dampak bisa mengarah pada etnocide dimana jati diri kesukuan sangat terancam dan bahkan hilang, karena tidak adanya pengaturan terhadap hak-hak hidup sesuai dengan cara hidupnya.

Seiring dengan kemajuan zaman, ketenangan dan ketentraman hidup masyarakat Suku Anak Dalam di pedalaman hutan belantara tidak dapat berlangsung terus. Sedikit demi sedikit hutan yang menjadi habitat mereka mulai berkurang 
akibat eksploitasi hutan secara besar-besaran yang dilakukan oleh industri kelapa sawit dan oknum-oknum yang melakukan penebangan liar (illegal logging). Mereka diancam akan dibunuh, bahkan eksploitasi hutan dan pembukaan lahan perkebunan kelapa sawit di kawasan hutan adat mereka terus meningkat. Di tengah berbagai keterbatasan pada permasalahan tersebut di atas, arang rimbapun harus berjuang mempertahankan kelangsungan kehidupannya dalam mengatasi remasalahan perusakan hutan. Salah satu Rimba yaitu Tumenggung Tarib menjadi perintisnya. Tumenggung Tarib pernah mendapat Kehati Award dalam kategori perintis lingkungan rada tahun 2000 . Hal ini sebagai salah satu contoh thahwa orang rimba dalam menjaga hutan atau -mba telah mendapat pengakuan dan diapresiasi alieh negara.

Berdasar dari hasil observasi tentang kehidupan Suku Anak Dalam (Orang Rimba), selanjutnya alieh penulis sebagai penata tari dijadikan sebagai landasan untuk diekspresikan ke dalam bentuk karya tari. Proses eksplorasi sebagai proses awal pencarian gerak, penata tari (penulis) terjun langsung di tengah-tengah masyarakat Suku Anak Dalam di Bukit Dua Belas Propinsi Jambi. Melihat secara langsung bagaimana karakteristik Suku Anak Dalam (Orang Rimba), dan terlibat dalam aktivitas sehari-hari mereka di dalam rimba belantara. Proses selanjutnya penulis sebagai penata tari bersama penari pendukung melakukan eksplorasi di hutan dekat makam seniman Girisapto Imogiri Kabupaten Bantul. Hal tersebut dilakukan disebabkan konsep garapan tari ini mengangkat tentang kehidupan Orang Rimba. Aktivitas tersebut dilakukan untuk merangsang panca indera penata tari dan penari dalam berimajinasi serta merasakan suasana hutan.

Bentuk penyajian garapan karya tari "Rim-Ba" adalah tentang penggambaran aktivitas seharihari Orang Rimba dengan permasalahan sosial yang melingkupi kehidupan mereka. Gambaran yang divisualisasikan yaitu alunan senandung rimba dan ucapan salam kepada dewa penunggu rimba sebagai bagian dari ritual mereka; mencari makanan secara tradisional yaitu mencari umbiumbian, mencari ikan dengan cara menangkap (mengakop) dan menombak; berburu binatang buruan seperti babi, rusa dan sebagainya; mencari buah-buahan dan lebah madu; melakukan aktivitas melangun (berpindah tempat). Selain itu digambarkan pula ekspresi ketidakberdayaan dan ketakutan Orang Rimba terhadap permasalahan sosial. Ruang gerak aktivitas tradisional mereka semakin sempit disebabkan adanya eksploitasi secara besar-besaran yang dilakukan oleh idustri kelapa sawit dan adanya penebangan liar (illegal logging). Dampak dari aktivitas perusakan hutan tersebut menyebabkan terjadinya perubahan sosial. Pada saat ini sebagian kecil dari mereka harus mengemis dipinggir jalan yang berdekatan dengan Taman Nasional Bukit Duabelas.

\section{Konsep Penciptaan}

Garapan tari ini dilatar belakangi oleh kedekatan secara geografis penata tari yang berasal dari Propinsi Jambi dengan kehidupan Suku Anak Dalam (Orang Rimba) di Bukit Duabelas Propinsi Jambi. Beraktivitas serta berinteraksi dengan Suku Anak Dalam bagi penata tari sudah menjadi hal biasa dalam kesehariannya. Penata tari berusaha untuk merasakan suasana kehidupan Suku Anak Dalam dengan melebur di tengahtengah masyarakat Suku Anak Dalam (Orang Rimba). Hal tersebut dilakukan dengan tujuan agar dapat membangkitkan seluruh potensi panca indra agar dapat menangkap segala fenomena yang dimungkinkan dapat dituangkan ke dalam garapan tari. Konsep dasar itu dicoba untuk diaktualisasikan ke dalam sebuah garapan tari.

Tema merupakan hal yang paling mendasar atau penting dalam sebuah karya tari. Tema tari sendiri dipahami sebagai pokok permasalahan yang mengandung isi atau makna tertentu dari sebuah koreografi baik literal maupun non literal (Hadi, 2003: 89). Tema yang diangkat dalam karya tari ini adalah perjuangan hidup Suku Anak Dalam (Orang Rimba). Semangat hidup Orang Rimba dalam mempertahankan hidupnya di dalam hutan yang terasa semakin sempit oleh penebangan liar maupun perluasan lahan perkebunan kelapa sawit.

Judul yang dipilih pada garapan karya tari ini adalah "Rim-Ba". Kata Rim-Ba terdiri dari dua suku kata, yaitu Rim dan Ba. Menurut Tumenggung Tarip Rim , berarti pelan, tenang, atau hening, dan $\mathrm{Ba}$ berarti rimba di Taman Nasional Bukit Duabelas, ada bunga ada dewa. Apabila hutan rusak berarti tidak ada bunga 
dan dewa, hal tersebut akan mengakibatkan punahnya budaya Orang Rimba. Oleh karena itu kata Rim-Ba mengandung maksud bahwa hutan di Bukit Duabelas merupakan rumah, sumber penghidupan dan perlindungan bagi Suku Anak Dalam (Orang Rimba) yang harus tetap dijaga ketenangannya. Terkait dengan karya tarinya, kata Rim-Ba dapat diartikan sebagai kritik tubuh terhadap perusakan alam yang ada. Karya tari ini merupakan media pemberitahuan tentang aktivitas kehidupan Orang Rimba yang sangat tergantung dengan alam hutan di Bukit Duabelas Propinsi Jambi. Sebuah harapan bagi masyarakat pada umumnya untuk peduli terhadap kehidupan Orang Rimba serta hutan sebagai habitat kehidupannya.

Tipe tari dalam karya tari ini adalah tipe tari dramatik yang memuat sebuah cerita (literal). Alur cerita dalam karya tari Rim-Ba ini dibagi menjadi empat bagian dengan uraian sebagai berikut, yaitu: Adegan pertama diawali dengan introduksi sebagai penggambaran perjuangan orang rimba atas fenomena yang terjadi di luar rimba, seperti modernisasi, serta hinaan masyarakat luar terhadap pola hidup mereka. Adegan dua menggambarkan sifat keprimitifan Orang Rimba sebagai penghuni hutan belantara di Bukit Duabelas, dengan para dewa yang melindungi mereka di dalamnya. Adegan tiga berisi tentang cara bertahan hidup Orang Rimba di Taman Nasional Bukit Duabelas Jambi. Misalnya aktivitas sehari-hari Orang Rimba secara tradisional yaitu mencari lebah madu, mencari umbi-umbian, mencari buah-buahan, berburu, mencari ikan, melakukan aktivitas budaya melangun pada saat sedang menghadapi remayo (paceklik). Adegan empat menggambarkan kesedihan Orang Rimba, sikap berontak dan rasa geram mereka terhadap perubahan sosial yang sedang terjadi, seperti adanya illegal loging, dan pembukaan lahan pertanian oleh industri kelapa sawit. Hal ini berdampak terhadap semakin sempitnya sumber kehidupan dan penghidupan Orang Rimba. Bagian akhir dari karya tari ini adalah dampak pada kondisi sosial Orang Rimba itu sendiri, yaitu mengemis di pinggir jalan.

Mode penyajian dalam garapan karya tari ini simbolis representasional, merupakan salah satu cara ungkap sebagai penyampaian maksud dan makna baik secara langsung maupun tidak langsung. Gerak-gerak reprensentatif yang hadir merupakan gerak realis atau gerak keseharian yang berkembang menjadi gerak simbolik. Penyajian karya tarinya menghadirkan suasana hutan belantara seperti menampilkan akar gantung, daun dan batang pohon secara abstrak, dan aktivitas orang rimba yang diwujudkan melalui gerak tari berbentuk simbol-simbol yang memiliki makna di dalamnya.

\section{Konsep Penggarapan}

Konsep penggarapan koreografi memerlukan beberapa unsur yang berfungsi sebagai pembentuk karya tari. Ada beberapa unsur yang utama dalam pembentukan sebuah karya tari yaitu gerak, musik, penari, property serta tata teknik pentas. Elemen tersebut disatukan dengan ide dan tema yang disampaikan oleh penata tari melalui karya tari sehingga apa yang diungkapkan penata tari dapat tercapai.

\section{Gerak Tari}

Tari merupakan komposisi gerak yang telah mengalami penggarapan melalui proses stilisasi dan distorsi. Berbagai unsur dari seni tari misalnya ialah gerak dan arah (The Liang Gie, 1996: 104). Gerak sebagai elemen dasar tari memiliki peranan penting dalam mengkomunikasikan maksud sebuah garapan tari kepada penonton. Instrumen tubuh tidak hanya bergerak tanpa tujuan, namun gerak yang dihadirkan memiliki makna dan maksud tertentu sesuai dengan ide garapan. Materi gerak yang dihadirkan dalam karya tari ini dari aspek kreativitas gerak lebih bebas sesuai dengan kemampuan tubuh. Orientasi gerak berangkat dari perilaku gerak keseharian Orang Rimba. Sebagai dasar dalam pengembangan gerak tari, penata tari terlebih dahulu mencoba untuk terlibat secara langsung di tengahtengah kehidupan Orang Rimba. Dalam proses eksplorasinya dicoba untuk membebaskan diri dalam melakukan pencarian gerak-gerak secara realis misalnya gerak mencari umbi-umbian, berburu, mencari ikan, mencari lebah madu, mencari rotan, dengan mempertimbangkan aspek tenaga, ruang, dan waktu. Kualitas gerak tari yang dihadirkan, agar lebih optimal digunakan teknik dasar sacrum, yang berfungsi sebagai pengontrol keseimbangan dan kelincahan dalam bergerak. Penggarapan gerak tari yang dihasilkan diharapkan 
Tata cahaya merupakan pendukung agar pertunjukan lebih bisa dinikmati, sekaligus dapat membangun suasana yang disampaikan, selain itu tata cahaya juga mampu memberikan gambaran yang jelas tentang dinamika garapan karya tari ini. Jenis lampu yang digunakan dalam pertunjukan garapan ini adalah general light, spot light, special light, wash light.

Tata rias sangat penting dalam pertunjukan tari yang fungsinya dapat merubah dari wajah aslinya baik yang mempunyai karakter maupun yang tidak. Bentuk tata rias penari putra dalam garapan ini adalah menggunakan rias natural make-up dengan tujuan dapat memberikan efek pada wajah penari agar lebih segar dan dapat menyerupai dengan aslinya pada saat di atas panggung. Sedangkan warna yang dipilih adalah coklat, hitam dan warna-warna yang sifatnya natural agar terkesan kotor. Penari putri hanya menggunakan bedak yang hanya mempertegas garis-garis wajah, ditambah dengan lipstick (pemerah bibir) warna natural. Seluruh tubuh penari dilumuri dengan bubuk kopi. Salah satu penari putra yang berbeda karakternya dengan penari lain, adalah penggunaan body painting dengan menggunakan karakter pohon.

Desain tata rias rambut, untuk penari putri diikat menjadi satu ikatan pada bagian belakang kepala yang kemudian dibuat kusut dengan menggunakan hair spray, dan ditaburi bedak agar kelihatan berdebu. Pada penari putra ditata sedemikian rupa dengan menggunakan hair spray dan ditaburi bedak, agar kelihatan seperti tidak terurus. Rancangan busana atau kostum yang dikenakan dalam garapan ini adalah mengimitasi pakaian yang dikenakan oleh Orang Rimba. Busana yang dikenakan oleh dua penari putra yaitu cancut atau cawat dan penari putri menggunakan sejenis kemben warna coklat, tight pendek warna coklat muda dan ditutup rok pendek warna coklat. Satu Penari putra mengenakan kostum yang menyerupai dengan kayu. Jenis kostum yang dipakai oleh seluruh penari menggunakan bahan yang menyerupai kulit kayu yang berwarna coklat. Satu penari dengan karakter kayu menggunakan bahan spon ati, dibalut dengan kain warna coklat, kemudian dibentuk dan dicat sedemikian rupa sehingga menyerupai pohon.
Properti yang digunakan dalam penggarapan karya tari ini sama dengan alat yang dipakai untuk beraktivitas sehari-hari Orang Rimba ketika mencari makanan di dalam rimba yaitu ambung besar satu buah dan dua buah kayu, dua instalasi kayu, dan tali gantung (akar gantung). Properti ambung tersebut digunakan sebagai penggambaran alat untuk mencari lebah madu, buah- buahan, dan mencari umbi-umbian. Properti kayu yang pada saat-saat tertentu dieksplor penari sebagai simbol tombak yang berfungsi untuk menombak ikan dan berburu. Keberadaan instalasi kayu merupakan sebagai simbol pepohonan, pada saat tertentu oleh penari dipakai untuk memanjat, dan seutas tali sebagai simbol akar gantung digunakan untuk bergelantungan.

Tata suara yang berupa sound system dilengkapi empat speaker pada setiap sudut arena pentas digunakan sebagai fasilitas, dapat berfungsi untuk memperjelas musik pengiring tarinya agar kualitas suara yang dihasilkan dapat maksimal. Peralatan elektronik yang digunakan adalah CD player, karena hasil akhir dari editing musik dengan komputer tersebut adalah $\mathrm{CD}$ dengan format $\mathrm{CD}$ audio.

\section{Proses Penggarapan \\ Proses Observasi}

Observasi dilakukan di Taman Nasional Bukit Duabelas, Kecamatan Hitam Ulu, Kabupaten Sarolangun, Propinsi Jambi. Dalam proses ini penata tari dapat merasakan suasana kehidupan Suka Anak Dalam (Orang Rimba). Selain itu juga dalam tahap ini dilakukan wawancara antara penata tari dengan nara sumber untuk menggali berbagai informasi yang diperlukan. Nara sumber tersebut adalah Datuk Tarib, yang menjabat sebagai Temenggung Suku Anak Dalam di kawasan sungai Makekal yang merupakan salah satu tokoh dari Suku Anak Dalam (Orang Rimba). Proses tersebut dilakukan untuk memperoleh suatu konsep garap tari agar kebebasan kreatif tetap dibingkai oleh suasana kehidupan Suku Anak Dalam. Beberapa di antaranya adalah tentang keberadaan kelompok Suku Anak Dalam (Orang Rimba) terbagi menjadi tiga kategori yaitu keberadaan Suku Anak Dalam (Orang Rimba) yang bermukim di dalam hutan dan hidup berpindah-pindah, kelompok Suku Anak Dalam 
(Orang Rimba) yang hidup di dalam rimba dan menetap, kelompok Suku Anak Dalam (Orang Rimba) yang pemukimannya dekat dengan pemukiman orang luar (penduduk biasa), asal-usul Orang Rimba dan Ritual adat Suku Anak Dalam. Data-data yang diperoleh kemudian dicoba untuk dievaluasi dengan mempertimbangkan kemungkinan aspek koreografinya. Beberapa yang dipilih sebagai pijakan dasar konsep garapan karya tari, yaitu tentang keberadaan Suku Anak Dalam (Orang Rimba) yang bermukim di dalam hutan dan hidup berpindah-pindah. Pengamatan ini lebih memfokuskan pada pola kehidupan mereka, cara bertahan hidup tradisional mereka, dan permasalahan sosial yang terjadi. Oleh karena itu diharapkan karya tari yang dihasilkan dapat optimal sehingga dapat memberikan pesan moral bagi para penikmat seni.

Hasil observasi yang diperoleh penata tari dari uraian tersebut di atas adalah sikap dan perilaku orang terang (masyarakat biasa) terhadap Orang Rimba, yaitu orang terang menyebut Suku Anak Dalam dengan sebutan Kubu, yang artinya terbelakang, dan memperlakukannya seperti orang bodoh. Penata tari dalam hal ini juga merasakan adanya perbedaan tersebut, meskipun demikian mereka tetap menikmati hidup mereka. Mata pencaharian untuk mempertahankan hidup mereka di dalam Rimba adalah mencari umbiumbian, mencari lebah madu, mencari buahbuahan, mengakop ikan, berburu binatang buruan. Sedikit demi sedikit hutan yang menjadi habitat mereka mulai bekurang akibat eksploitasi hutan secara besar-besaran, dilakukan oleh industri kelapa sawit dan oknum-oknum yang melakukan penebangan liar (illegal logging). Sehingga dapat mempersempit ruang hidup mereka di dalam rimba.

\section{Proses Eksplorasi}

Upaya untuk mengetahui sejauh mana penguasaan tubuh dalam bergerak, maka penggarapan diawali dengan melakukan proses eksplorasi. Pengertian eksplorasi adalah suatu proses penjajagan, yaitu sebagai pengalaman untuk menanggapi obyek dari luar, meliputi berpikir, berimajinasi, merasakan, dan merespon (Hadi, 2003: 65). Eksplorasi awal dimulai dengan hidup bersama di antara Suku Anak Dalam di Taman Nasional Bukit Duabelas Propinsi Jambi, serta bersama penari di salah satu hutan di daerah Imogiri, yaitu lokasi yang dekat dengan makam seniman. Hal tersebut dimaksudkan agar setiap individu penari dapat menumbuhkan cipta, rasa dan karsa terhadap obyek garapan tari ini. Selain itu juga pada proses selanjutnya dilakukan pencarian teknik gerak memanjat pohon dan bergelantungan di akar, pada obyek pengamatan yang ada.

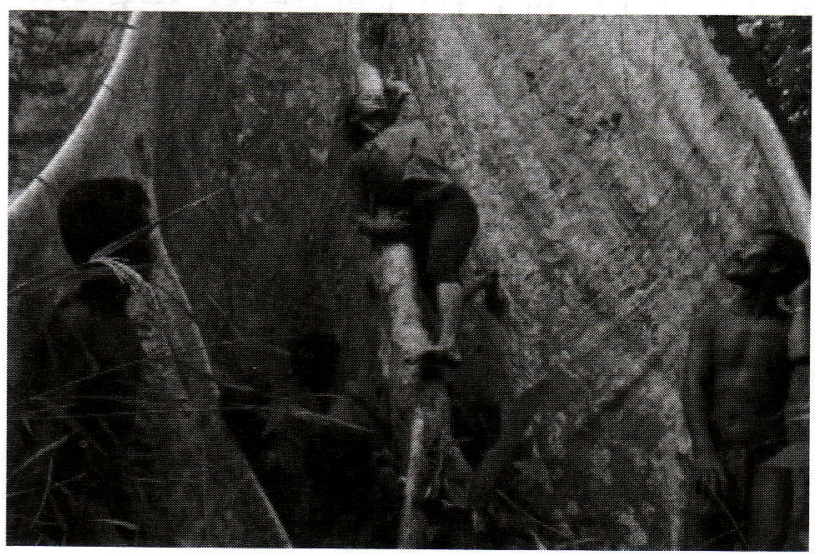

Penata tari (memanjat pohon) melakukan eksplorasi di antara Suku Anak Dalam di tengah hutan

.Taman Nasional Bukit Duabelas Propinsi Jambi (Foto: Dokumen Widyanarto, 2009)

\section{Proses Improvisasi}

Improvisasi diartikan sebagai penemuan gerak secara kebetulan atau spontan, walaupun gerakgeraktertentu munculdarigerak-gerak yang pernah dipelajari atau ditemukan sebelumnya, tetapi ciri spontanitas menandai hadirnya improvisasi (Hadi, 2003: 69-70). Proses improvisasi juga merupakan penjelajahan gerak, kaitannya dengan pengayaan gerak secara tidak sadar akan muncul gerak tertentu yang dirasa cocok dengan imajinasi yang direncanakan oleh penata tari. Sehubungan dengan hal tersebut di atas, dalam penggapan karya tari ini dihadirkan pada bagian-bagian tertentu akan menghadirkan gerak improvisasi yang dilakukan oleh seluruh penari. Hal ini dilakukan dengan mempertimbangkan karakter gerak, ekspresi jiwa, penekanan suasana atau dinamika gerak yang dihadirkan pada konsep garapan karya tari "RimBa”.

\section{Proses Koreografi}

Proses koreografi melalui penyeleksian merupakan proses pembentukan atau penyatuan materi tari yang telah ditemukan (Hadi, 2003: 
72). Di dalam proses koreografi kelompok, proses pengembangan materi telah dimulai dari pengalaman eksplorasi dan improvisasi secara bersama antara penata tari dengan penari. Langkah ini diambil guna mencari bentukbentuk-bentuk gerak tari dan menyeleksi gerak dari hasil proses eksplorasi dan improvisasi. Gerak-gerak yang ditemukan kemudian digali dan disusun menjadi sekumpulan motif gerak. Proses tersebut dilakukan bersama penari dengan tujuan untuk menyeleksi baik dari segi estetis maupun teknik gerak. Proses selanjutnya yaitu mengkomposisikan atau pengorganisasian bentuk untuk mengarahkan karya tari ke sebuah bentuk ekspresif yang mampu mengkomunikasikan ide atau gagasan kepada penikmat seni atau penonton.

\section{Proses Evaluasi}

Evaluasi dalam proses penggarapan tari merupakan suatu penilaian yang harus dilakukan oleh penata tari pada tahap-tahap tertentu, misalnya dalam proses berkarya sampai karya tersebut dipentaskan. Hasil yang telah dicapai setelah akhir proses penggarapan karya dievaluasi untuk perbaikan. Proses evaluasi dilakukan melalui berbagai cara, seperti pengamatan, diskusi, masukan dari berbagai pihak untuk perbaikan. Hal tersebut diperlukan agar mendapatkan hasil yang maksimal. Pada proses penggarapan karya tari "Rim-Ba", proses evaluasi dilakukan penata tari selama proses kreatif berlangsung. Namun demikian hal tersebut tidak merubah struktur alur cerita secara keseluruhan.

\section{Penutup}

Karya tari "Rim-Ba" merupakan karya tari yang sangat menarik dan unik untuk dikaji. Gagasan awal dari garapan karya tari ini berawal dari hasil pengamatan terhadap objek berbagai macam peristiwa dan kehidupan Suku Anak dalam (Orang Rimba) di Propinsi Jambi. Orang Rimba adalah masyarakat hutan yang benarbenar tinggal dan hidup di dalam keteduhan dan kelebatan hutan. Mereka memanfaatkan seluruh ruang hutan bagi kehidupan, filosofi hidupnya bersumber pada kehidupan hutan. Kehidupan yang unik dan eksotik adalah sebuah atmosfir kehidupan mereka. Di tengah peradaban dunia yang melaju cepat mereka masih saja terikat dalam kehidupan seperti yang dilaksanakan oleh nenek moyang mereka. Tema yang dipilih dari garapan karya tari ini adalah perjuangan hidup orang rimba.

Materi gerak yang dihadirkan dalam karya tari ini, hasil dari proses pengamatan secara langsung terhadap Orang Rimba. Proses selanjutnya lebih membebaskan penata tari dalam melakukan kreativitas gerak sesuai dengan kemampuan tubuh. Sumber gerak berangkat dari perilaku gerak kehidupan Orang Rimba sendiri. Bentuk penyajian garapan dalam karya tari "Rim-Ba" ini adalah adegan I merupakan introduksi tentang keterbelakangan, adegan II tentang ritus rimba, adegan III tentang orang rimba dalam aktivitas mata pencarian, dan adegan IV tentang perusakan rimba yang merupakan bagian untuk menuju klimaks dan ending. Garapan ini sebagai salah satu wujud kepedulian umat manusia (dalam hal ini penata tari) di bumi ini dalam menyikapi masalah illegal loging dan global warming.

\section{Kepustakaan}

Aritonang, Robert. 2005. Alam Sumatra, Penindasan terhadap suku asli. Jambi: Warsi.

Hadi, Y. Sumandiyo. 2003. Aspek-Aspek Dasar Koreografi Kelompok. Yogyakarta: ELKAPHI.

Hawkins, Alma M. 1988. Creating Through Dance. Terjemahan Y. Sumandiyo Hadi, Yogyakarta: Manthili.

Meri, La. 1965. Dance Composition, The Basic Elements, Massachusetts: Jacobs Pillow Dance Festival.

Smith, Jacqueline. 1985. Komposisi Tari: Sebuah Petunjuk Praktis Bagi Guru, diterjemahkan oleh Ben Suharto. Yogyakarta: Ikalasti.

The Liang Gie. 1996. Filsafat Seni Sebuah Pengantar. Yogyakarta: Pusat Belajar Ilmu Berguna.

\section{Informan}

R. Irwansyah, 50 tahun, Kepala bagian pendoku mentasian Taman Budaya Jambi.

Sri Purnama, 46 tahun, seniman tari di Jambi. Tumenggung Tarib, 65: tahun, sebagai Tumenggung sungai Makekal Taman Nasional Bukit Dua Belas Propinsi Jambi.

Zurhadmi Ismail, 60 tahun, pengamat kebudayaan daerah Jambi. 